\title{
子宮頸部細胞診からみた子宮体癌 およびその関連病変について
}

\author{
国立金沢病院産婦人科1)，同 研究検查科2) \\ 丹後 正紘 ${ }^{1)}$ 渡辺騏七郎 ${ }^{2)}$
}

子宮体癌およびその前癌病変が通常の子宮頸部細胞診からどの程度診断可能であるか検討した。 子宮体癌 76 例中 71 例 $(93.4 \%)$ が不正出血を訴えて来院し, その胵塗抹では 67 例 $(88.2 \%)$ に 内膜腺細胞集塊を認め, 44 例 (57.9\%) が陽性であった. 内膜の上皮内腺癌と異型增殖症を合わせ て 15 例中, その胵塗抹では 12 例 $(80.0 \%)$ に内膜腺細胞集塊を認め, 5 例 $(33.3 \%)$ が陽性また は疑陽性であった。腺腫様増殖症 23 例中，その胵塗抹では 15 例（65.2\%）に内膜腺細胞集塊を認 め，5例 (21.7\%) が陽性または疑陽性と判定された。

腟塗抹に扔いてまず弱拡大で内膜の細胞集塊をみつけたら強拡大で核小体の有無に注目し, 核小 体を有したら, 重積性の有無, 極性, 核の腫大, 細胞質の量や性状から, 正常内膜細胞や内膜の修 復細胞と鑑別することが可能である.

とにかく閉経後の胵塗抹に内膜細胞がみられたら, 十分注意を払うことによって胵塗抹による体 癌の検出率を向上させることができると考えている.

Key words : Endometrial carcinoma-Cervical cytology-Screening

\section{I. はじめに}

高齢化社会を迎え，閉経以後の婦人人口が増加し，体 癌の好発年齢層が拡大されたこと, あるいは生活様式の 欧米化が進んできたことなどによって，今後体癌の増加 が予想される。その対策の必要性が叫代れ，老健法のへ ルス事業として体癌検診が行われることになり，効率的 な癌検診として成立させるためにスクリーニングの対象 は不正出血を認めるものに選定された。しかし Koss $ら^{10)}$ は浸潤癌でむ無症状の症例を報告し, 子宮内膜の細

Diagnosis of endometrial carcinoma and its related lesions by routine cervical cytology

Masahiro TANGO ${ }^{1}$, M.D., Kishichiro WATANABE ${ }^{2)}$, M.D.

${ }^{1}$ Department of Obstetrics and Gynecology, Kanazawa National Hospital

${ }^{2)}$ Department of Pathology, Kanazawa National Hospital 論文別刷請求先 寀920 金沢市石引 3 の 1 の 1 国立金沢病院 産婦人科 丹後正紘

平成元年 1 月 19 日受付

平成元年 8 月 25 日受理
胞診の第 1 目標は臨床的に疑われない状態で診断される べきだと述べている. 本来検診は無症状のらちに早期発 見し治療するのが理想であるから, 無症状の早期の体癌 を検出するには現在行われている頸癌検診の細胞診に頼 らざるを得ないことになる，そこで体癌およびその前癌 病変がどの程度, 通常の頸癌検診の細胞診に反映されて いるのか検討した.

\section{II. 対象および方法}

\section{1. 対 象}

研究対象は表 1 のごとくで, 1977 年から 1986 年まで の 10 年間に不正子宮出血, 不規則月経, 過長月経, 褐色 带下, 無月経, 不妊症, 下腹部痛等を訴えて当科を受診 し, 内膜組織診で診断された腺囊胞増殖症 (CGH) 184 例, 腺腫様增殖症 (ADH) 23 例, 異型増殖症 (ATH) と 内膜上皮内癌 (AIS) をあわせて 15 例, 内膜癌 (ECA) 76 例である. なお内膜生検時に不正出血を認めた症例は 表 2 のごとくである. 
表 1 内膜生検による子宮内膜病変の例数 （1977 1986 内膜生 検 13,848 例）

\begin{tabular}{l|rc|c}
\hline \hline & 閉経前 & 閉経後 & 計 \\
\hline cystic glandular hyperplasia & 147 & 37 & 184 \\
adenomatous hyperplasia & 16 & 7 & 23 \\
$\left.\begin{array}{l}\text { atypical hyperplasia } \\
\text { adenocarcinoma in situ }\end{array}\right\}$ & 4 & 11 & 15 \\
adenocarcinoma & 18 & 58 & 76 \\
\hline
\end{tabular}

表 2 内膜生検時の不正出血の頻度

\begin{tabular}{l|r}
\hline \hline cystic glandular hyperplasia & $159 / 184(86.4)$ \\
adenomatous hyperplasia & $20 / 23(87.0)$ \\
atypical hyperplasia & $12 / 15(80.0)$ \\
adenocarcinoma in situ & adenocarcinoma \\
\hline
\end{tabular}

\section{2. 方 法}

成人の外来初診患者全例に子宮腟部は木製のへラによ る擦過法で, さらに必要に応じて頸管内は青梅綿の綿棒 で擦過し, パパニコロー法で染色し鏡検した. 10 個以上 の子宮内膜腺細胞の集団を認めないものを $\mathrm{N}$ 群とし, 子宮内膜細胞の集団を認めるが，悪性とはいえないもの を $\mathrm{E}$ 群, 疑陽性または陽性の内膜腺癌細胞を認めるもの を $\mathrm{M}$ 群とし，1）子宮体癌および内膜増殖症の各々を $\mathrm{N}$ 群, $\mathrm{E}$ 群, $\mathrm{M}$ 群に分類し, さらに 2) 子宮体癌症例を閉 経前と閉経後に分けて各々の $\mathrm{N}$ 群, $\mathrm{E}$ 群, $\mathrm{M}$ 群の頻度を 比較した. また各病変閒の内分泌学的な差を比較するた めに, 3) 細胞成熟度指数を算定するには胵側壁採取の標 本によらねばならないが, 腟塗抹標本において炎症細胞 の混在の少ない症例について強拡大 (対物 40 倍, 接眼 10 倍) で 100 個の扁平上皮細胞を数えて, 表層細胞, 中 層細胞, 旁基底細胞の出現比率をみた. さらに 4) 内膜 増殖症と体癌 $\mathrm{I}$ 期の $\mathrm{G}_{1}, \mathrm{G}_{2}, \mathrm{G}_{3}$ ならびに体癌 II 期につ いて組織球の出現頻度を比較した. 炎症性細胞の多い視 野を強拡大 (400 倍) で 10 個しらべ, 組織球が平均 10 個 以上出現しているものを多数群とし, ほとんどみられな いものを少数群, その中間群との 3 つに分類した.

\section{III. 結 果}

\section{1. 子宮体癌および内膜增殖症の内膜腺細胞の出現頻 度}

子宮体癌症例の子宮頸部細胞診において，陽性または 疑陽性を示す M 群は $57.9 \%$ であった. 低分化になるに つれて $\mathrm{M}$ 群の頻度は高かった. 子宮体癌 76 例中内膜細
表 3 子宮体癌の内膜腺細胞の出現頻度

\begin{tabular}{c|c|rrr}
\hline \hline & 例数 & N群 & \multicolumn{1}{c}{ E群 } & \multicolumn{1}{c}{ M群 } \\
\hline $\mathrm{G}_{1}$ & 50 & $6(12.0)$ & $17(34.0)$ & $27(54.0)$ \\
$\mathrm{G}_{2}$ & 16 & $2(12.5)$ & $4(25.0)$ & $10(62.5)$ \\
$\mathrm{G}_{3}$ & 10 & $1(10.0)$ & $2(20.0)$ & $7(70.0)$ \\
\hline $\mathrm{Fi}^{+}$ & 76 & $9(11.8)$ & $23(30.3)$ & $44(57.9)$ \\
\hline \multicolumn{4}{l}{}
\end{tabular}

N群: No endometrial cells 群

E群: Endometrial cells 群

M群：Malignant endometrial cells 群

$\mathrm{G}_{1}$ : well differentiated adenocacinoma

$\mathrm{G}_{2}$ : moderately differentiated adenocarcinoma

$\mathrm{G}_{3}$ : poorly differentiated adenocarcinoma

胞の出現がほとんど認められないものはわずか $11.8 \%$ であった（表 3 ).

子宮内膜増殖症の子宮頸部細胞診において，陽性また は疑陽性を示すものは, $\mathrm{CGH}$ では $9.8 \%, \mathrm{ADH}$ では $21.7 \%$ ATH と AIS では $33.3 \%$ と病変の進行とともに 陽性または疑陽性率の上昇がみられた（表 4 ）。

\section{2. 閉経前之閉経後の子宮体癌症例の内膜細胞出現頻 度の比較}

子宮体癌症例を閉経前と閉経後に分けて，各々の子宮 頸部細胞診に出現する内膜腺細胞をしらべると表 5 のご とくで，閉経後の方が疑陽性，陽性細胞の出現頻度が高 かった.

\section{3. 扁平上皮細胞における表層細胞の比率}

正常の卵胞期 10 例, 黄体期 10 例, 閉経後 5 年以内の 閉経初期 10 例, 閉経後期 10 例を対象にして閉経後の子 宮体癌 10 例について扁平上皮細胞中の表層細胞の 占め る割合についてしらべ，その平均を表 6 に示した．体癌 例では閉経後でも $31 \%$ の表層細胞の出現がみられ，対 照に比して有意に高い出現率であった. 図 1 では閉経前 と閉経後の体癌，異型増殖症，正常例における扁平上皮 細胞中の表層細胞の占める割合をグラフに示し比較し た（表 7 ).

\section{4. 組織球の出現頻度}

内膜増殖症と内膜癌 I 期との間には有意差はみられな かったが，【期では明らかに I 期より出現頻度は高かっ た（表 7 ).

\section{IV. 考案}

通常の子宮頸部細胞診における体癌検出率は 40〜70 \%といわれており ${ }^{6,7,13)}$, 著者らの成績でも疑陽性を含 めて $57.9 \%$ であったが，頸部細胞診にどのような所見 
表 4 子宮内膜増殖症の内膜腺細胞の出現頻度

\begin{tabular}{l|r|rrr}
\hline & 例数 & N群 & E群 & M群 \\
\hline cystic glandular hyperplasia & 184 & $82(44.6)$ & $84(45.7)$ & $18(9.8)$ \\
adenomatous hyperplasia & 23 & $8(34.8)$ & $10(43.5)$ & $5(21.7)$ \\
atypical hyperplasia & 15 & $3(20.0)$ & $7(46.7)$ & $5(33.3)$ \\
adenocarcinoma in situ & & & & $($ ) 内 \%
\end{tabular}

表 5 閉経前と閉経後の子宮体癌症例の内膜腺細胞の 出現頻度

\begin{tabular}{c|c|rrr}
\hline \hline & 例数 & N 群 & E 群 & \multicolumn{1}{c}{ M群 } \\
\hline 閉経泊 & 18 & $4(22.2)$ & $6(33.3)$ & $8(44.4)$ \\
閉経後 & 54 & $5(8.6)$ & $17(29.3)$ & $36(62.0)$ \\
\hline
\end{tabular}

N群: No endometrial cells 群

E 群: Endometrial cells 群

M群 : Malignant endometrial cells 群

表 6 扁平上皮細胞における表層細胞の比率

\begin{tabular}{lr}
\hline \hline 旁基底細胞/中層細胞/表層細胞の百分比 \\
\hline 正常の卵胞期 (10例) & $7 / 33 / 60$ \\
黄 体 期 (10例) & $4 / 64 / 32$ \\
閉 経 初 期 (10例) & $34 / 46 / 20$ \\
閉 経 後 期 (10例) & $52 / 40 / 8$ \\
閉経後子宮体癌 (10例) & $18 / 51 / 31$ \\
\hline
\end{tabular}

表 7 内膜病変の頸管スメアにおける組織球の出現頻度

\begin{tabular}{|c|c|c|c|c|}
\hline & 例数 & 少数 & 中等度 & 多数 \\
\hline cystic glandular hyperplasia & 10 & 7 & 2 & 1 \\
\hline adenomatous hyperplasia & 10 & 8 & 1 & 1 \\
\hline $\left.\begin{array}{l}\text { atypical hyperplasia } \\
\text { adenocarcinoma in situ }\end{array}\right\}$ & 10 & 7 & 1 & 2 \\
\hline adenocarcinoma $\mathrm{G}_{1}$ & 10 & 4 & 3 & 3 \\
\hline$G_{2}$ & 10 & 5 & 3 & 2 \\
\hline $\mathrm{G}_{3}$ & 10 & 5 & 3 & 2 \\
\hline 1 期 & 10 & 5 & 3 & 2 \\
\hline 2 期 & 10 & 3 & 2 & 5 \\
\hline
\end{tabular}

多数：400倍顕微鏡下で 10 個以上

中等度 : 400 倍顕微鏡下で 5,6 個

少数：目立たない

がみられたら，体癌あるいはその前癌病変を疑って検索 すべきなのか retrospective に検討した.

\section{1. 子宮頸部細胞診における内膜異型細胞の判定}

佐藤ら ${ }^{23)}$ は子宮体癌の細胞診診断基準として点数法を 考案し，1）核の大小不同，2）核小体，3）核クロマチン, 4) 細胞の重積性, 5) 細胞の出現形式を観察項目として いるが,この中で第一の特徴は Meisels ら ${ }^{15)}$ も述べてい るが,不規則重積性を示す細胞集塊の出現である.体癌で

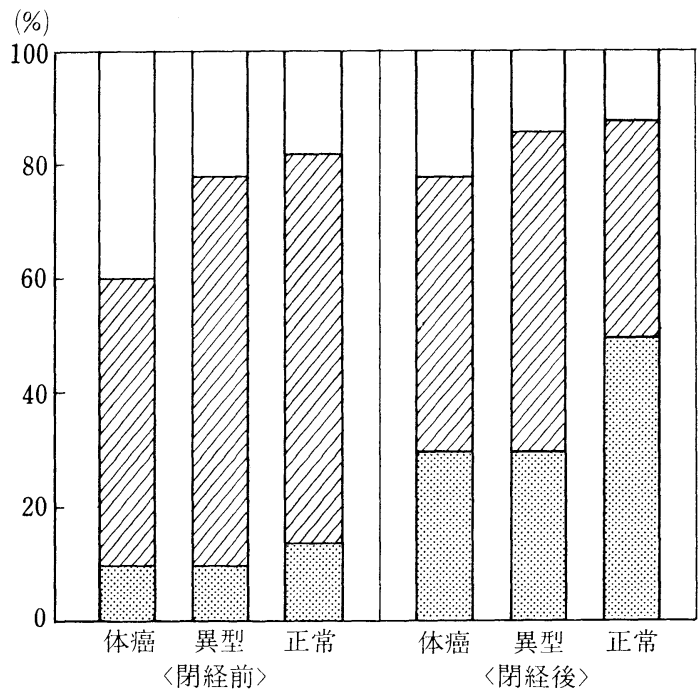

旁基底細胞 ZZय中層細胞 表層細胞

図 1 体癌・異型増殖 - 正常婦人の扁平上皮細胞に おける表層細胞の比率

は重積性集塊がみられる一方，低分化になるにつれて細 胞間の結合性が弱くなるためか, 小川ら ${ }^{21)}$ も指摘してい るが，孤立性の異型細胞の出現がみられる。一般に内膜 腺細胞の細胞質は目立たなく，核径は比較的小型である ため, 特に腫瘍性背景がみられる場合には, 弱拡では見 逃してしまいやすいので注意が必要である (写真 1 ). 内 膜増殖症は細胞の異型度が低いので, 構造異型に注目す べきといわれておりり ${ }^{2,24)}$, 野田 ${ }^{19)}$ は $\mathrm{ADH}$ で腺腔の開口 と思われる集塊の中の空間に向かって著しい細胞の重積 がみられる例を載せているが，この㹡張した腺腔形成は 著者らも $\mathrm{ADH} 23$ 例中 15 例 (65.2\%) に認め, 特徵ある 所見の一つである(写真 2 ).

第二の特徴は核の腫大である ${ }^{1,4)}$. とにかく重積性の細 胞集塊を認めたら, 強拡にして森沢ら ${ }^{16)}$ も述べている が，集塊辺縁もしくはその付近の孤立した内膜細胞に注 目し，核径の大小不同の程度を観察する。核径の大小を 比較するのに好中球の核径 $(10 \sim 15 \mu)$ や扁平上皮の中 


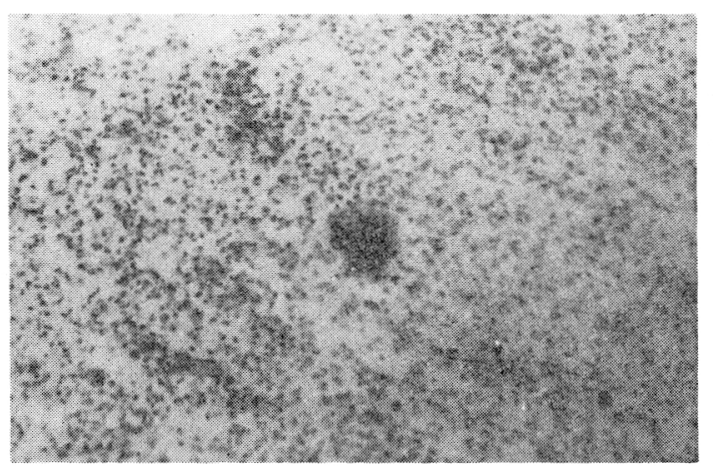

写真 1 腫瘍性背景の中の内膜癌細胞

核径が小型なので弱拡では見逃しでしまう危険がある

$(100 x)$

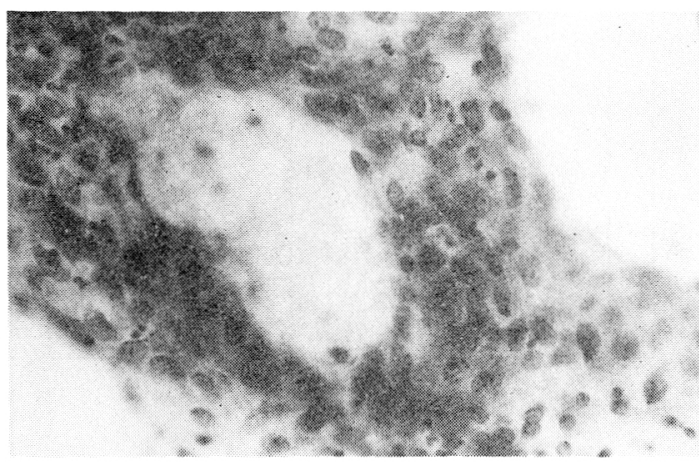

写真 2 子宫内膜異型增殖症由来の細胞

腺管の開口部に向かって重層化がみられ，小型の内膜 細胞に核小体がみられる $(400 x)$

層細胞の核径 (7〜12 $\mu)$ と比較するのが有用とされてい る ${ }^{18)}($ 写真 3$)$ ，正常子宮内膜細胞の核径は，ほぼ中層細 胞の核径程度であるが，正常細胞においても最大の核径 が最小の核径の 2 倍ぐらいの大小不同はみられるが，内 膜増殖症や内膜癌になると, 永井ら ${ }^{17)}$ の報告にもみられ るように，大小不同はさらに著しく，2 倍を越える大小 不同がみられる。

第三の特徴は，核小体の出現である.CGH ではほとん ぞの異型細胞に核小体は認められないが (写真 4), 異型 性が增すにつれて，核小体が多くの異型細胞に出現して くる．内膜癌ではほとんどの癌細胞に核小体を認め，增 淵ら ${ }^{14)}$ も述べているように, $\mathrm{G}_{1}$ で核核小体は余り目立た ない例が多いが, $G_{2}, G_{3}$ では橙赤色の著明な核小体を認 める. 子宮内操作後や IUD 使用者にみられる修復細胞 にも著明な核小体を認め, 内膜癌との鑑別が難しい例 ${ }^{3)}$ が報告されているが，病歴に注意し，修復細胞の配列は 平面的で，細胞質が豊富であり，境界がはっきりしてい て，国井ら ${ }^{12)}$ も指摘しているが，クロマチンが微細で均

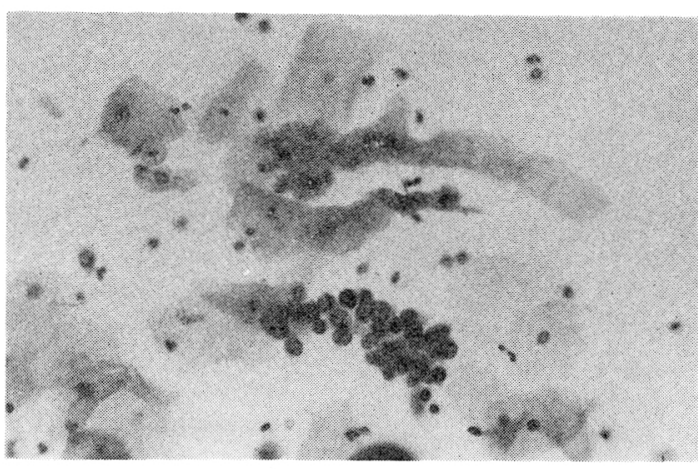

写真 3 高分化型体部腺癌細胞

小型のため弱抎では見逃しやすい，扁平上皮の中層細 胞の核径の 2 倍以上の核径である $(200 \times)$

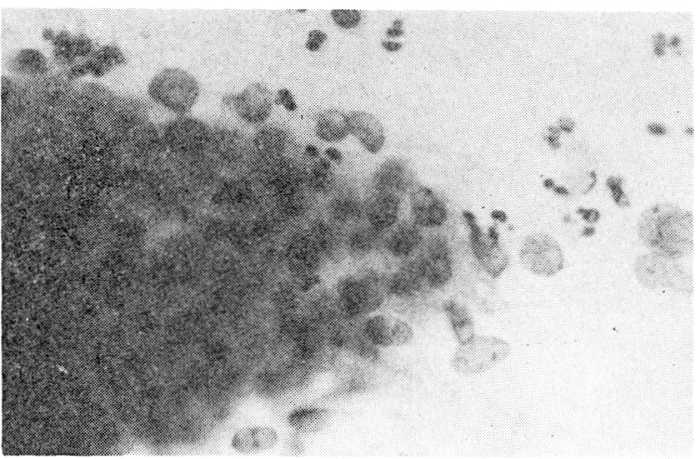

写真 4 腺囊胞増殖症の細胞

重積性は軽度で, 集塊の辺縁に裸核状で, 核の大きさ は正常の内膜細胞の核の 2 倍ぐらいで，核小体を有しな い細胞が散在性に認められる $(400 \times)$

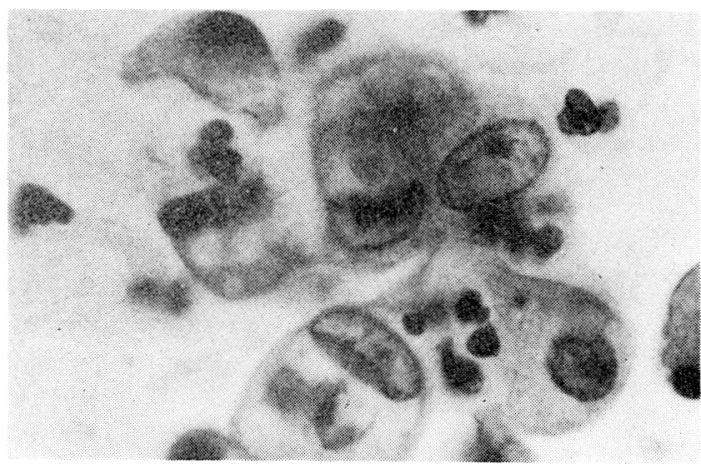

写真 5 低分化型内膜腺癌細胞

高倍率にすると核縁の肥厚，核小体が著明になってくる. euchromatin の白色化のため核内は明るくみえる $(1000 \times)$

一な分布を示している点などから鑑別可能である。

第四の特徵はクロマチンの分布状態である.CGH では 微細で均一な分布を示すが, ADH, AIS と異型性が増す につれて，伊藤ら5) も述べているように，クロマチンは 
増量し, 粗で不均等分布を示すため, 核内が濃染してい る部分と明るくぬけてみえる部分がみられる.内膜癌で は分化度が低くなるにつれて塩基性色素にほとんど染ま らない euchromatin によって核内が白くぬけて明るく みえる細胞が多くみられる(写真 5 ).

\section{2. 子宮頸部細胞診における内膜細胞の出現}

閉経後の婦人の胵塗抹に，正常異常にかかわらず，と にかく内膜細胞が存在する場合や，閉経前の婦人でも， 月経周期の第 12 日以後の胵塗抹になお内膜細胞が存在 する場合は悪性病変を疑ってさらに検索すべきだといわ れているが $\left.{ }^{9} 20\right)$, 今回の著者らの成績でも, 体癌におい て，とにかく良性悪性にかかわらず内膜細胞が出現した 頻度は $\mathrm{G}_{1}$ で 50 例中 44 例 $(89.0 \%), \mathrm{G}_{2}$ で 16 例中 14 例 (87.5\%), $\mathrm{G}_{3}$ で 10 例中 9 例 $(90.0 \%)$ であった. 悪性細 胞の出現には筋層浸潤の深さより子宮腔内における病栄 の大きさが深く関与しているといわれているが8,22)，著 者らの成績でも同様の傾向がみられた. 子宮内膜増殖症 の内膜細胞の出現率は, $\mathrm{CGH}$ で $55.4 \%, \mathrm{ADH}$ で $65.2 \%$, ATH と AIS では $80 \%$ と異型性が増すにつれて出現率 が高くなった.

\section{3. 扁平上皮細胞中の表層細胞の占める比率}

体癌患者では高エストロゲン環境にある者が多いとい われており, Koss ${ }^{11)}$ は閉経後の患者の腟塗抹に扁平上皮 細胞の過熟性がみられることを指摘している. 成熟度指 数を算定するには本来は胵側壁から採取した炎症を示さ ないスミアで行うこととされているが, 鈴木ら ${ }^{25)}$ の胵顓 部細胞診における成熟度指数を調べた成績でも体癌症例 の半数近くが高エストロゲン環境 (KPI 高值, MI 右方 移動）にあったと述べている．著者らの成績でも同様に， 閉経後の子宮体癌症例に捛いて, 表層細胞の出現頻度が 対照例に比して有意に高かった. 細胞診で年齢に比して 表層細胞の出現率が高い場合には, 体癌の存在も考慮し て, 精查すべきである.

\section{4. 腫瘍性背景と組織球の出現}

白血球, 赤血球の浸潤に加え, 細胞破片や壊死物質な どが多数認められる症例を腫愓性背景ありとすると，鈴 木 ${ }^{25)}$ 住体癌 30 例の頸部細胞診上に明らかな腫瘍性背景 が認められたものはわずか 3 例 $(10 \%)$ で，これらの 3 例はいずれも頸部浸潤が確認されたものであったと述べ ている．著者らの成績でも体癌の分化度と組織球の出現 頻度には差がみられなかったが，II期の方が I 期よりも 明らかに組織球の出現頻度が高かった。 内膜増殖症では ほとんどが背景が比較的きれいで，異型度と組織球の出 現頻度に差がみられなかった。頸部の細胞診において， 組織球の出現頻度が目立つ例で注進行癌も考慮する必要
があると考えられる。

\section{V. ま とめ}

子宮体癌およびその関連病変を通常の頸癌検診で検出 することはかなりの熟練を要するが，まず弱拡大で内膜 の細胞集団をみつけたら強拉大で核小体の有無に注目 し, 核小体を有したら, 重積性の有無, 核の腫大, 極性, 細胞質の量や性状から, 正常内膜細胞や内膜の修復細胞 と鑑別することが可能である.

とにかく閉経後の腔塗抹に内膜細胞がみられたら，十 分注意を払うことによって腟塗抹による体癌の検出率を 向上させることができると考えている.

1）子宮体癌 76 例中 71 例 $(93.4 \%)$ が不正出血を訴 えて来院し, その胵塗抹では 67 例 $(88.2 \%)$ に内膜腺細 胞集塊を認め, 44 例 (57.9\%) が陽性であった.

2) 内膜の上皮内膜癌と異型增殖症を合わせて 15 例 中, その胵叙抹では 12 例中 $(80.0 \%)$ に内膜腺細胞集塊 を認め，5例 (33.3\%) が陽性または疑陽性であった。

3) 腺腫様増殖症 23 例中, その腟塗抹では 15 例 (65.2\%) に内膜腺細胞集塊を認め，5例 (21.7\%) が陽 性または疑陽性と判定された。

\section{Summary}

This study was conducted to ascertain how routine cervical smear findings could be used to reliably predict endometrial carcinoma and its related lesions. The results are as follows :

1. Of 76 women with endometrial carcinoma, $71(93.4 \%)$ complained of abnormal uterine bleeding, 67 (88.2\%) presented clusters of endometrial cells and $44(57.9 \%)$ were positive.

2. Of 15 women with endometrial carcinoma in situ or atypical hyperplasia, $12(80 \%)$ presented clusters of endometrial cells and $5(33.3 \%)$ were suspect or positive.

3. Of 23 women with adenomatous hyperplasia, 15 (65.2 $\%)$ presented clusters of endometrial cells and $5(21.7 \%)$ were suspect or positive.

If in the routine cervical smear clusters of endometrial cells are found under low-power microscopy, the nucleoli should be examined under high power. Among endometrial cells with nucleoli, it is possible to differentiate suspect or positive cells from normal or repair cells by observing cell overlap, appearance and checking for anisonucleoli and scanty cytoplasm.

It should be emphasized that the presence of endometrial 
cells in routine cervical smears of postmenopaused women requires further investigation of the endometrium. This will improve the accuracy of diagnosis of endometrial carcinoma and its related lesions.

\section{文献}

1) Cherkis, R.C., Patten, S.F. and Dickinson, J.C., et al. : Significance of atypical endometrial cells detected by cervical cytology, Obstet. Gynecol., 69 : 786 789, 1987.

2）長谷川寿彦, 高橋峰夫, 木口一成・他: 子宮体部一内膜增 殖症・内膜癌一, 産婦実際, $34: 1687 \sim 1693,1985$.

3）林玲子, 上坊敏子, 蔵本博行：無症状者に対する子宮体 癌検診, 日臨細胞誌, $26: 1 \sim 6,1987$.

4）井上 悟, 伊藤昌春, 東谷俊光・他: 子宮体癌およびその 前癌病変の細胞診, 日臨細胞誌, $23: 524 \sim 531,1984$.

5）伊藤治英, 関根達征, 小室順義 : 子宮内膜病理組織診断一 の手引き, 産婦実際, $35: 1647 \sim 1654,1986$.

6）和泉 滋, 木口一成, 筒井章夫 - 他 : 子宮内膜癌診断法の 価值と限界, A. 細胞診による子宮内膜癌の診断, 産婦実際, $30: 1629 \sim 1637,1981$.

7）金子義晴, 柳原敏宏, 荻野満春 - 他 : 胵・頸部細胞診によ る子宮体癌の診断一特に採取部位と病理学的所見との関連 について一, 日臨細胞誌, $23: 127 \sim 131,1984$.

8）木寺義郎, 岩坂 剛, 塚本直樹 - 他: 子宮体癌の細胞診に ついて一特に病理学的特徵との関連性について一, 日臨細 胞誌, $20: 504 \sim 508,1981$.

9) Koss, L.G., Schreiber, K., Oberlander, S.G., et al. : Screening of asymptomatic women for endometrial cancer, Obstet. Gynecol., $57:$ 413, 1981.

10) Koss, L.G. : Diagnostic cytology and its histopathologic bases. Third edition, p. 412, J.B. Lippincott, Philadelphia, 1979.

11) Koss, L.G. : Diagnostic cytology and its histopathologic bases. Third edition, p. 437, J.B. Lippincott, Philadelphia, 1979.

12）国井勝昭, 国井兵太郎, 大橋洋子 - 他 : 子宮内膜再生細胞
と子宮缅部, 体部腺癌細胞との比較検討, 日 臨 細 胞 誌, $24: 36 \sim 43,1985$.

13）蔵本博行, 森沢孝行, 下田隆夫・他：子宮体内膜の細胞診 採取法, 産婦実際, $35: 1 \sim 8,1986$.

14）増濎誠夫, 秦 宏樹, 藤本郁野・他: 体癌の細胞診, 産婦 治療, $44: 205 \sim 209,1982$.

15) Meisels, A., Jolicoeur, C. : Criteria for the cytologic assessment of hyperplasias in endometrial samples obtained by the endopap endometrial sampler, Acta Cytologica, $29: 297 \sim 302,1985$.

16）森沢孝行, 蔵本博行, 上坊敏子・他：子宮内膜緇胞診の新 しい擦過採取法について, 日臨細胞誌, $21: 520 \sim 525$, 1982.

17）永井荘一郎，沢田富夫：子宮内膜癌および内膜增殖症に関 する細胞診断学的研究, 日産婦誌, $35: 2283 \sim 2290,1983$.

18）根本裕樹，岡島弘幸，鈴木忠雄・他：子管体癌細胞診にお ける Criteria, 日臨細胞誌, $22 ： 720 \sim 725 ， 1983$.

19）野田 定: 産婦人科細診マニュアル，p. 63 ，永井書店，大 阪, 1987.

20) Ng, A.B.P., Reagan, J.W., Hawliczek, S. and Wentz, B.W. : Significance of endometrial cells in the detection of endometrial carcinoma and its precursors, Acta Cytologica, $18: 356 \sim 361,1974$.

21）小川英式，備前美輝子，真木正博：子宫体部悪性腫瘍の諭 断に㧍ける Endocyte 法と増淵式吸引法との比較, 日臨細 胞誌, $23: 517 \sim 523,1984$.

22）斎藤聰史，山下幸紀，西野共子・他：子宮体癌における子 宮頸部擦過スメアについて, 産と婦, $51: 1733 \sim 1737$, 1984.

23）佐藤伸子, 石田禮載, 千綿教夫・他：子宮体癌の細胞診診 断基準作成の試み一特に新しい採点法の考案一, 日臨細胞 誌, $23: 395 \sim 402,1984$.

24）鈴木忠雄：子宮体癌と細胞診，産婦治療，52：436 439, 1986.

25）鈴木光明，大和田倫孝，玉田太朗：腟・頸部細胞診による 子宮内膜癌の診断一特に背景に出現する細胞像の特徴につ いて一，日臨細胞誌， $22: 578 \sim 585 ， 1983$. 